\title{
Cyperus limiticola, a New Name for a Madagascan Cyperus (Cyperaceae)
}

\author{
Isabel Larridon*, Marc F. M. Reynders, and Paul Goetghebeur
}

Ghent University, Department of Biology, Research Group Spermatophytes, K. L.

Ledeganckstraat 35, 9000 Gent, Belgium. *Corresponding author: isabel.larridon@ugent.be

Abstract. There is a need to propose a new name in Cyperus L. for C. paucispiculatus Chermezon because the name currently used is an illegitimate later homonym of C. paucispiculatus Böckeler. A new name, C. limiticola Larridon \& Reynders, is provided here.

Key words: Cyperaceae, Cyperus.

In 1884, Böckeler described Cyperus paucispiculatus Böckeler [= Pycreus divulsus (Ridley) C. B. Clarke]. Chermezon (1919) used C. paucispiculatus Chermezon for a new species from Madagascar and placed it in its own section, Cyperus sect. Paucispiculati Chermezon. The latter species does not belong to the genus Pycreus P. Beauvois, and so is not related to P. divulsus, although both species show a reduction in the number of spikelets. Cyperus paucispiculatus Chermezon is a later homonym of $C$. paucispiculatus Böckeler and is therefore illegitimate (McNeill et al., 2006: Art. 53.1). A new name, $C$. limiticola Larridon \& Reynders, is proposed. The epithet, which means "inhabiting the edge," refers to the natural surroundings in which the plant was collected (i.e., the edge of the forest).

Cyperus limiticola Larridon \& Reynders, nom. nov. Replaced name: Cyperus paucispiculatus Chermezon, Bull. Soc. Bot. France 66: 342. 1919 [1920], non Cyperus paucispiculatus Böckeler, 1884. TYPE: Madagascar. [Antananarivo]: Distr. Manjakandriana, lisière de la forêt à l'Est d'Ambatolaona, $1400 \mathrm{~m}, 11$ Nov. 1912, R. Viguier \& J.-H. Humbert 1256 (holotype, P 00450832; isotypes, P 00450833, P 00581793). Figure 1.

Caespitose perennial herb with a slender rhizome; culms filiform, $15-35 \mathrm{~cm} \times$ ca. $0.5 \mathrm{~mm}$, smooth. Leaves few, slightly shorter than the culms, ca.
$0.5 \mathrm{~mm}$ wide, setaceous, semicylindrical, smooth, leaf sheaths fuscous. Lower involucral bract smooth, erect, continuing in the direction of the culm, up to $3-6 \mathrm{~cm}$, setaceous; second involucral bract glumiform; anthela composed of 1 to 3 radii; radii $0-4 \mathrm{~cm}$, erect, with short prophylls and 1 or 2 spikelets; spikelets compressed, ovate-lanceolate, ca. $5 \times 2.5 \mathrm{~mm}$, with 5 to 7 flowers; rachilla winged. Glumes slightly imbricate, ovate-lanceolate, shortly mucronate, ca. $3 \mathrm{~mm}$, subrigid, the sides yellow-brown, with 2 or 3 obscure lateral nerves, midrib narrow, smooth, green, 3-nerved; stamens 3; anthers linear, connectives shortly setiferous; style deeply trifid. Achenes immature.

Discussion. Chermezon (1919) stated that, with its multinervate glumes and its setiferous anthers, this isolated species only approaches the sections Cyperus sect. Diffusi (Kunth) C. B. Clarke and Cyperus sect. Debilissimi Chermezon, from which it is, however, sufficiently distinct, by its inflorescence and its leaves, to deserve its own section. Molecular research may offer an answer to its taxonomic relationships, although sadly this species is only known from its immature type specimens.

Acknowledgments. We thank M. Pignal (P) for the loan of the specimens examined for this study.

\section{Literature Cited}

Böckeler, O. 1884. Neue Cyperaceen. Bot. Jahrb. Syst. 5: $497-498$.

Chermezon, H. 1919 [1920]. Cyperus nouveaux de Madagascar. Bull. Soc. Bot. France 66: 338-353.

McNeil, J., F. R. Barrie, H. M. Burdet, V. Demoulin, D. L. Hawksworth, K. Marhold, D. H. Nicolson, J. Prado, P. C. Silva, J. E. Skog, J. H. Wiersema \& N. J. Turland (editors). 2006. International Code of Botanical Nomenclature (Vienna Code). Regnum Veg. 146. 

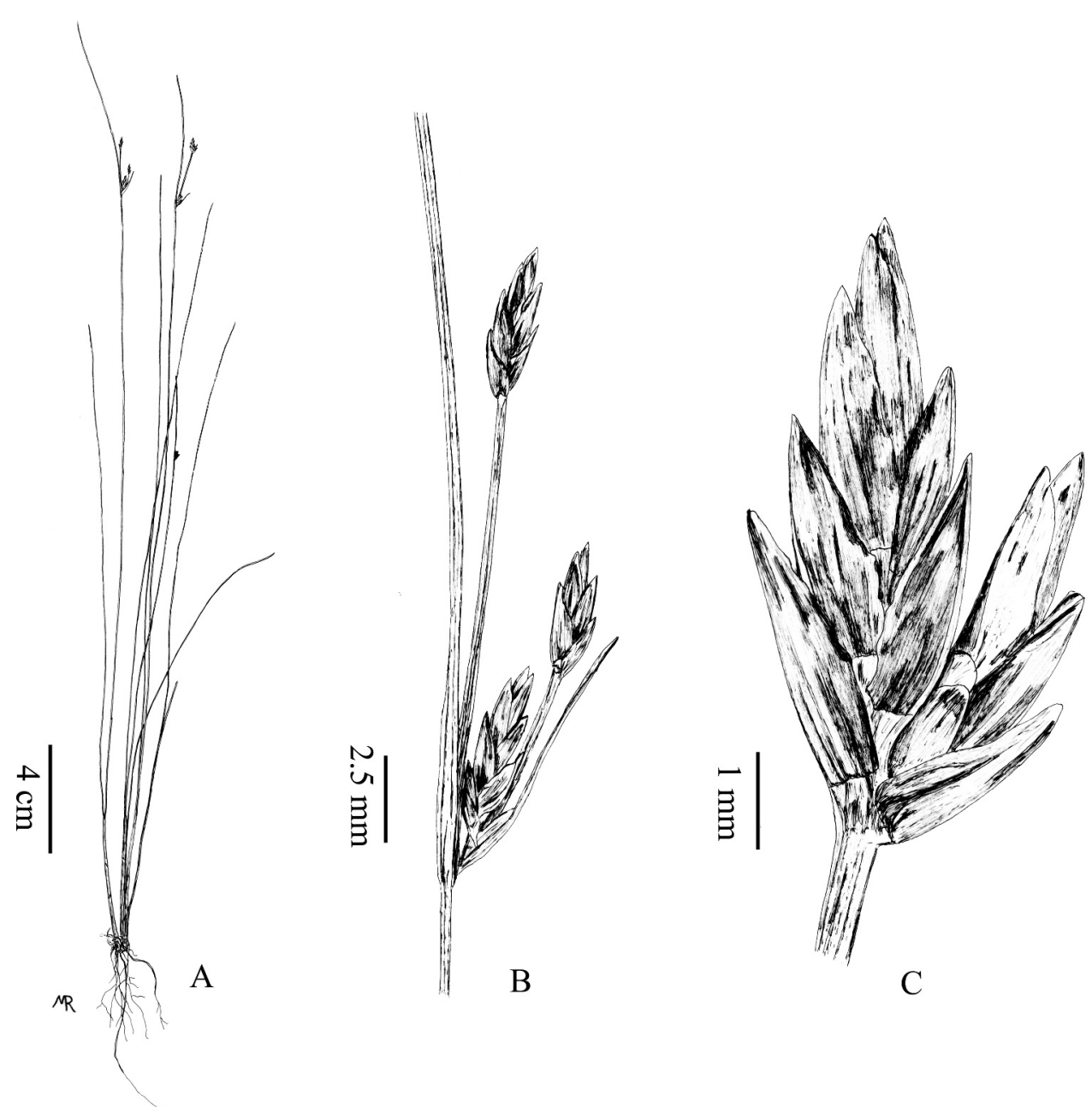

Figure 1. Cyperus limiticola Larridon \& Reynders. —A. Habit. —B. Inflorescence. —C. Detail of spikelets. Drawn by Marc Reynders from the holotype Viguier \& Humbert 1256 (P). 